\title{
The response of digestive enzyme activity in the mature Chinese mitten crab, Eriocheir sinensis (Decapoda: Brachyura), to gradual increase of salinity
}

\author{
RUIFANG WANG ${ }^{1,2}$, PING ZHUANG ${ }^{1,2}$, GUANGPENG FENG ${ }^{1}$, LONGZHEN ZHANG $^{1}$, \\ XIAORONG HUANG ${ }^{1}$, FENG ZHAO ${ }^{1}$ and $\mathrm{YU} \mathrm{WANG}^{1}$ \\ ${ }^{1}$ East China Sea Fisheries Research Institute, Chinese Academy of Fishery Sciences, Shanghai 200090, China. \\ E-mail: pzhuang@online.sh.cn \\ ${ }^{2}$ School of Life Science, East China Normal University, Shanghai 200062, China.
}

SUMMARY: Mature Chinese mitten crabs, Eriocheir sinensis, were exposed to brackish water or seawater as an obligatory part of their reproductive migration. Physiological and biochemical reorganization were needed to adapt them to this migration. To understand the digestive adjustments of Eriocheir sinensis at biochemical level during this transformation from freshwater to seawater, the response of the activity of five digestive enzymes (amylase, cellulase, pepsin, trypsin and lipase) in the hepatopancreas to salinities increasing gradually from 0 (freshwater) to 35 (seawater) was analysed in mature females and males. Digestive enzymes exhibited significantly higher activities in the hepatopancreas of males than those of females, except lipase. In females, amylase, pepsin and trypsin activities began to decrease significantly as the salinity reached 28 , and cellulase activity decreased at 35 ; in males, a considerable decrease in the activity of digestive enzymes, except lipase, was observed at 21 and higher salinities, while an increase was observed at 14. Reduced enzyme activities at elevated salinities suggest that the digestive capacity of crabs for diets becomes weak, and all these digestive enzymes participated in digestive adjustments during osmoregulation. The initial salinity which induced the decrease of enzyme activity was lower in males than in females, indicating that females were more tolerant to elevated salinities than males from the point of digestive biochemical modulation.

Keywords: mature crab, digestive enzyme, sexual difference, metabolic regulation, osmoregulation, salinity.

RESUMEN: RESPUESTA DE LA ACTIVIDAD ENZIMÁTICA DIGESTIVA AL INCREMENTO GRADUAL DE LA SALINIDAD EN EL CANGRejo de Shanghai maduro, ERIocheir sinensis (Decapoda: Brachyura). - Se expusieron cangrejos de Shanghai maduros (Eriocheir sinensis) a agua salobre o agua marina obligatoriamente durante la migración reproductora. A fin de que los ejemplares se adaptaran a esta migración, fue preciso proceder a una reorganización fisiológica y bioquímica. Con objeto de estudiar los ajustes digestivos de carácter bioquímico del Eriocheir sinensis durante la transformación del agua dulce en agua marina, se analizó la reacción de la actividad en el hepatopáncreas de cinco enzimas digestivas (amilasa, celulasa, pepsina, tripsina y lipasa) a un aumento gradual de la salinidad, desde 0 ppt (agua dulce) hasta $35 \mathrm{ppt}$ (agua marina), en ejemplares maduros machos y hembras. Las enzimas digestivas mostraron un grado de actividad notablemente mayor en el hepatopáncreas de los machos que en el de las hembras, con excepción de la lipasa. En las hembras, la actividad de la amilasa, la pepsina y la tripsina comenzó a reducirse notablemente cuando la salinidad alcanzó las 28 ppt, mientras que la actividad de la celulasa descendió cuando se alcanzaron las 35 ppt; en el caso de los machos, se observó un descenso muy pronunciado de la actividad enzimática digestiva a partir de las 21 ppt, aunque la actividad aumentó a las 14 ppt. La menor actividad enzimática indicaría que la capacidad digestiva de los cangrejos se reduce a niveles elevados de salinidad y que todas estas enzimas digestivas participan en los ajustes digestivos que se producen durante la osmorregulación. El nivel de salinidad inicial que indujo el descenso de la actividad enzimática fue inferior en los machos que en las hembras, lo cual indica que estas últimas mostraron una mayor tolerancia a un nivel elevado de salinidad que los machos desde el punto de vista de la modulación bioquímica del proceso digestivo.

Palabras clave: cangrejo maduro, enzima digestiva, diferencia por sexo, regulación metabólica, osmorregulación, salinidad. 


\section{INTRODUCTION}

Salinity is a key environmental factor governing the distribution of crustaceans that live in estuaries during all or part (migratory species) of their lives (Kinne 1966). They will acclimate to a gradual or abrupt change in environmental salinity through biochemical, physiological and/or behavioural readjustment in order to maintain the osmotic balance between their haemolymph and that of the medium (Anger 2001). Salinity acclimation may require metabolic reorganization and energy remodulation to meet the increased energetic demands associated with salinity change. Digestive enzymes are a part of the metabolic regulation mechanism in organisms. Enzymatic adaptation is defined as the variation of the quantity, and therefore of the activity, of enzymes when organisms are affected by external changes that modify their metabolic functions (Hochachka and Somero 1984). Though many studies have been conducted on decapod crustaceans to examine aspects of their responses to salinity stress, little information is available regarding the digestive aspects at a physiological and biochemical level (i.e. digestive enzyme activity). Two recent studies documented the digestive enzyme activity associated with environmental salinity in euryhaline decapods $(\mathrm{Li}$ et al. 2008, Asaro et al. 2011). Li et al. (2008) found that digestive enzyme activities of white shrimp, Litopenaeus vannamei, increased at extreme salinities. Asaro et al. (2011) reported that acclimating the euryhaline crab Neohelice (Chasmagnathus) granulata to low salinity (10 psu; hyper-regulating conditions) induced a significant increase in amylase activity. This information will enhance our comprehension of the biochemical and physiological strategies of crustaceans underlying osmoregulation.

The Chinese mitten crab, Eriocheir sinensis $\mathrm{H}$. Mine Edwards, 1853, belongs to the catadromous species, which spend most of their lives in rivers and lakes, but adult crabs have to return to the estuaries for reproduction (Herborg et al. 2006). Thereafter, embryos, zoeas and megalops of E. sinensis develop in estuaries, and when they moult to juveniles they start the upstream migration towards the limnic parental habitat (Herborg et al. 2003). Its unusual life cycle makes this species extremely euryhaline. E. sinensis has been used as model species for studying physiological regulation of crustaceans acclimating to a low osmotic environment from high salinity (Péqueux and Gilles 1981, Rathmayer and Siebers 2001); this acclimation mirrors the ecological conditions that the juvenile crabs experience in their natural environment during their upstream migration towards freshwater. However, this process takes place in reverse in the reproductive migration from freshwater to seawater of mature E. sinensis. To our knowledge, no work has been published on the physiological and biochemical adjustment that takes place in this migration.

Previous studies have investigated the activity changes of various digestive enzymes in E. sinensis during ontogeny (Pan and Wang 1997b, Shi et al. 2000) and gonadal development (Zhou et al. 2005) and in different geographical populations $(\mathrm{Li}$ and $\mathrm{Li}$ 1996). Furthermore, the effect of dietary nutrients (Jiang et al. 2005) and pollutants (Yang et al. 2005, Zhao et al. 2010) on enzyme activities has also been reported. However, studies on the modulation of digestive enzymes, in relation to environmental factors (i.e. salinity) are lacking. Field studies have demonstrated that ovigerous female $E$. sinensis feed little and/or fast during a later stage of development. This might be related to low temperature, deficiency in food and lower mobility of the animal (Panning 1938). However, no research has been done on whether the elevated salinity that the crabs experience during the reproductive period also exerts a direct physical action on digestive enzyme performance.

Our aim was to increase knowledge of the digestive biochemistry of $E$. sinensis to elevated salinity, as part of our integrative studies on the biochemical and physiological adaptation mechanisms of E. sinensis to elevated salinity during their reproductive migration. To this end, we determined the response to gradual elevated salinities of digestive enzyme activity in the hepatopancreas of E. sinensis. This study will also add to the scarce knowledge of digestive biochemical characteristics and enzyme responses of freshwater hyperregulators and euryhaline crustaceans to salinity acclimation.

\section{MATERIALS AND METHODS}

\section{Animal collection and maintenance}

Downstream migrating female and male Chinese mitten crab, Eriocheir sinensis (wet masses averaged $102.03 \pm 7.49$ and $116.23 \pm 14.03 \mathrm{~g}$, carapace width averaged $62.18 \pm 11.63$ and $62.58 \pm 2.61 \mathrm{~mm}$ of female and male crabs, respectively) were collected using trawl nets near the Baxu port $\left(120^{\circ} 27^{\prime} \mathrm{S}, 31^{\circ} 95^{\prime} \mathrm{W},<0.5\right.$ ppt, $19^{\circ} \mathrm{C}$ ), Jiangyin, China, P.R., which is near to the Yangtze estuary. The crabs were transported to the laboratory and divided into two groups according to sex. Females and males were kept separately in aquaria with dechlorinated tap water, an oxygen supply and a natural light/dark photoperiod for at least a week. The crabs were fed with snail meat on alternate days, but they were starved for two days prior to sampling. Water was changed on the intervening days.

\section{Experimental protocol}

Females and males were transferred to aquaria and were allowed to acclimate to five different salinities ( 7 , $14,21,28$, and $35 \mathrm{ppt})$ in a stepwise manner (3-4 ppt per day) up from tap water $(0 \mathrm{ppt})$. The experimental salinity was obtained by adding commercial sea salt to dechlorinated tap water and verified using a handheld refractometer. The crabs were kept at appropriate final 
salinity for three days to reach a stabilized osmolality (Roast et al. 2002). Nine animals per salinity, either females or males, were randomly anesthetized by immediately chilling on ice for about $30 \mathrm{~min}$. After removing the carapace, the crabs were rapidly dissected and the hepatopancreas were stored at $-80^{\circ} \mathrm{C}$ in $1.5-\mathrm{mL}$ plastic Eppendorf tubes until enzyme activity analysis. The mortality was zero throughout the experiment. No differences in feeding behaviour and food intake occurred between different salinities in either females or males. Mean $\left( \pm\right.$ SEM) water temperature was $18 \pm 1^{\circ} \mathrm{C}$, $\mathrm{pH} 8.2 \pm 0.2$, dissolved oxygen $7.96 \pm 0.72 \mathrm{mg} \mathrm{L}^{-1}$ and total ammonia nitrogen $0.077 \pm 0.10 \mathrm{mg} \mathrm{L}^{-1}$ within the experiment period.

\section{Analytical methods}

The frozen hepatopancreata were thawed in ice, weighed and homogenized in 1:5 (w/v) phosphate buffer $\left(0.025 \mathrm{M} \mathrm{KH}_{2} \mathrm{PO}_{4}, 0.025 \mathrm{M} \mathrm{Na}_{2} \mathrm{PO}_{4} 12 \mathrm{H}_{2} \mathrm{O}\right.$, pH 7.5). Part of the homogenates were immediately used for lipase analysis, and the rest of the homogenates were centrifuged at $100000 \mathrm{rpm}$ for $30 \mathrm{~min}$ at $4^{\circ} \mathrm{C}$. The supernatant was immediately used for other enzyme analysis. The total soluble protein content was measured in diluted homogenates by means of the Coomassie blue dye binding method, using bovine serum albumin as a standard. Pepsin and trypsin activity were evaluated according to Liu et al. (1991) using Folin-phenol reagent, with casein as a substrate. One unit of pepsin and trypsin was defined as the number of micrograms of tyrosine released per minute per milligram of protein. Amylase activity was performed using the method of Rick and Stegbauer (1984), with maltose as a standard and with starch as a substrate. One unit of amylase activity was defined as the number of micrograms of maltose released per minute per milligram of protein. Lipase and cellulose activities were assayed according to the method of Pan and Wang (1997a); activities were considered as the number of micromoles of fatty acids and micrograms of glucose released per minute per milligram of protein, using olive oil and sodium carboxymethylcellulose as a substrate, respectively. All digestive enzyme activities were expressed as a relative unit per milligram of soluble protein $\left(\mathrm{U} \mathrm{mg}^{-1}\right)$.

\section{Statistical analysis}

All values are presented as mean \pm SEM. The effect of the salinity and sex on digestive enzyme activities was analysed using two-way ANOVA. When significant interactions of the two factors were observed, the main effects were not further discussed but instead multiple comparison testing was performed to look at the simple effects. All statistical analyses were conducted using SPSS 16.0 for Windows. Normality and homogeneity of variances were previously checked. All differences were considered significant at $P<0.05$.

\section{RESULTS}

Digestive enzyme activities in hepatopancreas of mature females and males of E. sinensis at different salinities are shown in Table 1.

Two-way ANOVA showed that increased salinity has a significant effect on digestive enzyme activity. Sexual difference also has a significant effect on digestive enzyme activity and a significant interaction between salinity and sex was shown for digestive enzyme activity except that of lipase (Table 2).

In females, amylase activity did not significantly differ in the salinity range of 0.3-21 ppt, but it decreased significantly at 28 and 35 ppt $(P<0.05)$. In males, enzyme activity was stimulated after salinity was increased to $14 \mathrm{ppt}(P<0.05)$, and then decreased approximately two-fold at $21 \mathrm{ppt}(P<0.05)$ and maintained this activity from then on. Males showed significant higher amylase activity in hepatopancreas than females except at $21 \mathrm{ppt}$ throughout the experiment $(P<0.05)$.

In females, elevated salinity did not have a significant effect on cellulase activity until $28 \mathrm{ppt}(P>0.05)$.

TABLE 1. - Mean digestive enzyme activities in hepatopancreas of mature females and males of $E$. sinensis in response to increasing salinities (Mean \pm S.E.M, n=7-9); Unit: U/mg protein

\begin{tabular}{lcccccc}
\hline Gender & Salinity & Pepsin & Trypsin & Amylase & Cellulose & Lipase \\
\hline Female & 0 & $4.36 \pm 0.34^{\mathrm{ab}}$ & $0.54 \pm 0.09^{\mathrm{a}}$ & $64.69 \pm 5.88^{\mathrm{a}}$ & $3.26 \pm 0.42^{\mathrm{a}}$ & $2.62 \times 10^{-2} \pm 0.02^{\mathrm{a}}$ \\
& 7 & $4.93 \pm 0.53^{\mathrm{a}}$ & $1.14 \pm 0.09^{\mathrm{b}}$ & $65.39 \pm 6.61^{\mathrm{a}}$ & $2.94 \pm 0.34^{\mathrm{ab}}$ & $2.48 \times 10^{-2} \pm 0.02^{\mathrm{a}}$ \\
& 14 & $5.20 \pm 0.41^{\mathrm{a}}$ & $0.92 \pm 0.08^{\mathrm{ab}}$ & $61.56 \pm 5.65^{\mathrm{ab}}$ & $2.55 \pm 0.16^{\mathrm{ab}}$ & $4.63 \times 10^{-2} \pm 0.01^{\mathrm{a}}$ \\
& 21 & $4.75 \pm 0.49^{\mathrm{a}}$ & $1.21 \pm 0.10^{\mathrm{b}}$ & $67.88 \pm 7.03^{\mathrm{a}}$ & $2.85 \pm 0.27^{\mathrm{ab}}$ & $3.51 \times 10^{-2} \pm 0.02^{\mathrm{a}}$ \\
& 28 & $2.71 \pm 0.51^{\mathrm{bc}}$ & $0.23 \pm 0.07^{\mathrm{ac}}$ & $40.36 \pm 1.65^{\mathrm{bc}}$ & $1.86 \pm 0.27^{\mathrm{ab}}$ & $3.14 \times 10^{-2} \pm 0.01^{\mathrm{a}}$ \\
& 35 & $1.00 \pm 0.26^{\mathrm{c}}$ & $0.54 \pm 0.12^{\mathrm{ac}}$ & $30.56 \pm 3.02^{\mathrm{c}}$ & $1.76 \pm 0.32^{\mathrm{b}}$ & $0.60 \times 10^{-2} \pm 0.00^{\mathrm{a}}$ \\
Male & & & & & \\
& 0 & $7.29 \pm 0.46^{\mathrm{A}^{*}}$ & $1.39 \pm 0.09^{\mathrm{A}^{*}}$ & $151.35 \pm 4.96^{\mathrm{A}^{*}}$ & $6.27 \pm 0.46^{\mathrm{A}^{*}}$ & $3.51 \times 10^{-2} \pm 0.02^{\mathrm{A}}$ \\
& 7 & $7.51 \pm 0.47^{\mathrm{A}^{*}}$ & $1.26 \pm 0.06^{\mathrm{AC}}$ & $138.53 \pm 5.42^{\mathrm{A}^{*}}$ & $4.60 \pm 0.36^{\mathrm{B}^{*}}$ & $5.76 \times 10^{-2} \pm 0.02^{\mathrm{A}}$ \\
& 14 & $11.19 \pm 0.42^{\mathrm{B}^{*}}$ & $2.10 \pm 0.08^{\mathrm{B}^{*}}$ & $182.10 \pm 8.24^{\mathrm{B}^{*}}$ & $8.51 \pm 0.51^{\mathrm{C}^{*}}$ & $4.91 \times 10^{-2} \pm 0.02^{\mathrm{A}}$ \\
& 21 & $5.12 \pm 0.47^{\mathrm{C}}$ & $1.06 \pm 0.06^{\mathrm{C}}$ & $77.90 \pm 4.54^{\mathrm{C}}$ & $3.44 \pm 0.22^{\mathrm{BD}}$ & $5.51 \times 10^{-2} \pm 0.01^{\mathrm{A}}$ \\
& 28 & $5.92 \pm 0.34^{\mathrm{AC}}$ & $1.27 \pm 0.06^{\mathrm{AC}} *$ & $89.38 \pm 1.90^{\mathrm{C}^{*}}$ & $3.62 \pm 0.28^{\mathrm{BD}}$ & $2.45 \times 10^{-2} \pm 0.01^{\mathrm{A}}$ \\
& 35 & $2.21 \pm 0.39^{\mathrm{D}^{*}}$ & $1.39 \pm 0.10^{\mathrm{D}}$ & $70.93 \pm 5.50^{\mathrm{C}^{*}}$ & $2.93 \pm 0.43^{\mathrm{D}^{*}}$ & $2.40 \times 10^{-2} \pm 0.01^{\mathrm{A}}$ \\
\hline
\end{tabular}

Note: Different lowercase letters indicate statistically significant differences between salinity levels in females. Different capital letters denote significant differences between salinity levels in males $(P<0.05)$. The asterisks at the upper right of the capital letters indicate significant sexual differences at given salinity. 
TABLE 2. - The effect of salinity and sex on digestive enzyme activities was analysed using two-way ANOVA.

\begin{tabular}{lccc}
\hline Digestive enzyme & Salinity & Sex & Salinity $\times$ Sex \\
\hline Amylase & 0.000 & 0.000 & 0.000 \\
Cellulose & 0.000 & 0.000 & 0.000 \\
Pepsin & 0.000 & 0.000 & 0.000 \\
Trypsin & 0.000 & 0.000 & 0.000 \\
Lipase & 0.283 & 0.166 & 0.854 \\
\hline
\end{tabular}

The lowest enzyme activity was obtained at $35 \mathrm{ppt}$, this activity was significantly lower than that at freshwater $(P<0.05)$. In males, cellulase activity was considerably higher in freshwater and at $14 \mathrm{ppt}$ than at the other salinities. The enzyme activity decreased significantly at $21 \mathrm{ppt}(P<0.05)$, and then maintained this level until the end of the experiment. Cellulase activity in hepatopancreas was higher in males than in females except at $21 \mathrm{ppt}$ throughout the experiment $(P<0.05)$.

In females, an increase in salinity had no significant effect on pepsin activity over a salinity range of 0.3-21 ppt. The enzyme activity decreased at $28 \mathrm{ppt}(P<0.05)$, and reached the minimum at $35 \mathrm{ppt}$. In males, pepsin activity was significantly induced and reached the maximum at $14 \mathrm{ppt}$, and then decreased abruptly at 21 ppt and maintained this activity at $28 \mathrm{ppt}$; a further decrease of enzyme activity occurred at $35 \mathrm{ppt}(P<0.05)$. Males showed significantly higher pepsin activity in hepatopancreas than females except at $21 \mathrm{ppt}$ throughout the experiment $(P<0.05)$.

In females, trypsin activity significantly increased when salinity was increased to $7 \mathrm{ppt}$, and held this level until $21 \mathrm{ppt}$; a further increase of salinity to 28 ppt induced a significant decrease in enzyme activity, and this level was maintained until the end of the experiment. In males, trypsin activity increased significantly and reached a maximum level when salinity was increased to $14 \mathrm{ppt}$, decreased sharply at $21 \mathrm{ppt}$ and maintained this activity at $28 \mathrm{ppt}$, and then further decreased at $35 \mathrm{ppt}$ when it reached the lowest activity $(P<0.05)$. Trypsin activity in the hepatopancreas was significantly higher in males than that in females at freshwater, 14 and $28 \mathrm{ppt}(P<0.05)$.

In both females and males, lipase activity first increased and then decreased with the increase in salinity. However, no significant difference occurred between salinities in either females or males $(P>0.05)$.

\section{DISCUSSION}

The present study showed that all of the five digestive enzymes took part in the digestive adjustments of mature E. sinensis during their osmoregulation. The occurrence of five digestive enzymes in mature $E$. sinensis was consistent with previous studies (Shi et al. 2000, Zhou et al. 2005), which suggested that this species was capable of hydrolyzing carbohydrate, protein and lipid diets, and used them as nutrient sources. The existence of five digestive enzymes was also in agreement with the field investigation on their feeding nature that found that endemic and invasive $E$. sinensis was omnivorous and opportunistic in terms of its diets (Panning 1938, Chen et al. 1989, Hymanson et al. 1999, Rudnick et al. 2000), and fed preferably on algal-associated invertebrates and on shallow-dwelling invertebrates (Rudnick et al. 2005).

The digestive enzyme activity was generally consistent with the types of dietary material being ingested (Johnston and Freeman 2005). High amylase and cellulose activities reflected that the animals fed primarily on plant diets and were well equipped to utilize the carbohydrates within their diets. High levels of amylase and cellulose enzyme activities have been detected in $E$. sinensis during their ontogenetic development (Shi et al. 2000) and ovarian development (Zhou et al. 2005). In agreement with these findings, our results showed extremely higher amylase (females $30.56 \pm 3.02$

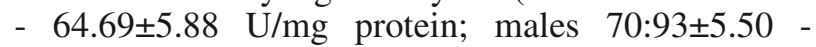
$151.35 \pm 4.96 \mathrm{U} / \mathrm{mg}$ protein) and quite higher cellulose activities (females: $1.76 \pm 0.32 \mathrm{U} / \mathrm{mg}$ protein; males: $2.93 \pm 0.43 \mathrm{U} / \mathrm{mg}$ protein) in the hepatopancreas of $E$. sinensis. This indicates that mature E. sinensis has great ability to digest carbohydrate. However, because snail meat was the only diet provided for E. sinensis during the entire experimental period, high amylase and cellulose enzyme activities could not related to the present diets, but was rather attributed to the previous secretion before reproductive migration in the river and lakes where adult crabs fed mainly on hydrophytes. Similar to the present results, cellulose activity has been detected in a wide range of aquatic invertebrates whose diets do not normally include substantial amounts of cellulose (Elyakova et al. 1981, Johnston 2003, Pavasovic et al. 2004). As proposed by Yokoe and Yasumasu (1964), the distribution of cellulose within the animal kingdom was more closely correlated with animal phylogenetic relationships than with differences and similarities in their feeding habits. Therefore, the present results seem to demonstrate further that the celluloses are produced endogenously in crustaceans (Crawford et al. 2004, Velurtas et al. 2011). Different substrates and assays for the determination of cellulose activity might also be responsible for the inconsistent results in the enzyme activity.

Lipase activity values found in our study were considerably lower than those of other digestive enzymes (Table 1), in accordance with previous studies on $E$. sinensis (Pan and Wang 1997b, Zhou et al. 2005). This finding might suggest that the diets did not include substantial amounts of lipid, so the crabs do not need to digest it. Consequently, low lipase activity was observed in the hepatopancreas. Furthermore, although numerous studies have reported lipase activity of crustaceans, the magnitude of the enzyme activity varied between them. This is likely related to the different substrates employed in the enzyme assays. In this study, we used olive oil as a substrate, while López-López et al. (2003) and Coccia et al. (2011) used $\alpha$-naphthyl caprylate as a substrate to detect the lipase activity, and other studies 
TABLE 3. - Medium osmolality and haemolymph osmolality of female and male (closed circles) Eriocheir sinensis H. Milne-Edwards, 1853 in response to increasing salinities (Mean \pm S.E.M, $n=7-9$ ).

\begin{tabular}{lrcr}
\hline Salinity & \multicolumn{3}{c}{ Osmolality/mOsm $\left(\mathrm{kg} \mathrm{H}_{2} \mathrm{O}\right)^{-1}$} \\
& \multicolumn{1}{c}{ Medium } & \multicolumn{1}{c}{ Male } \\
\hline Freshwater & $8 \pm 0.01$ & $622.40 \pm 3.73$ & $601.50 \pm 6.87$ \\
$7 \mathrm{ppt}$ & $175 \pm 1.88$ & $657.89 \pm 6.78$ & $669.67 \pm 5.90$ \\
$14 \mathrm{ppt}$ & $414 \pm 1.58$ & $719.57 \pm 8.89$ & $705.00 \pm 6.47$ \\
$21 \mathrm{ppt}$ & $631 \pm 4.72$ & $769.75 \pm 9.44$ & $768.56 \pm 6.96$ \\
$28 \mathrm{ppt}$ & $839 \pm 1.20$ & $840.13 \pm 8.26$ & $852.56 \pm 3.32$ \\
$35 \mathrm{ppt}$ & $1044 \pm 2.15$ & $1016.75 \pm 10.46$ & $1015.89 \pm 5.43$ \\
\hline
\end{tabular}

used other substrates (Rathelot et al. 1975, Gargouri et al. 1984, Gjellesvik et al. 1992). Some of these substrates might be not specific for lipase. A suitable substrate still needs to be found to standardize the lipase assays.

A change of environmental salinity appears to induce the metabolic reorganization of hyper-regulating crustaceans due to the increase or decrease in active ion uptake, which is an energy-costly process (Freire et al. 2008). Recently, Li et al. (2008) showed that trypsin and amylase activities increased in euryhaline pacific white shrimp Litopenaeus vannamei at extreme salinities. Similarly, Asaro et al. (2011) observed that amylase activity increased in the euryhaline crab Neohelice granulata in low environmental salinity. Elevated enzyme activities will enhance the digestive capacity of crustaceans for degrading diets and provide energy for osmoregulation. In agreement with these studies, the present study showed higher digestive enzyme activity as the crabs were maintained in freshwater or acclimated to lower salinities. Our study has demonstrated that mature E. sinensis strongly hyperregulated their hemolymph osmolality at a salinity range of 0-21 ppt (Table 3), and the isosmotic point approaching 28 ppt (Wang et al. 2012). Therefore, higher digestive enzyme activity in the relatively low salinity environment was a profitable response of the animal in an attempt to derive as much energy as possible from the food to meet its energy requirements for hyperregulation. On the other hand, digestive enzyme activity except that of lipase exhibited a decreasing tendency at relatively high salinities (21 or $28 \mathrm{ppt}$ ). The decrease in digestive enzyme activity in the present results at near to the isoosmotic environment might be an adaptive adjustment caused by the reduced energetic cost for ionic regulation; in this situation, the crabs decreased the energy derived from food.

Neurohormone seems to play important roles in altering feeding behaviour (Curtis and McGaw 2010) and modulating digestive enzyme activity (Wormhoudt 1974). Several studies (Mantel 1985, Kamemoto 1991, Morris 2001, Fanjul-Moles 2006) have also pointed out that neuroendocrine hormones are involved in the osmoregulation of crustaceans. However, no reports have directly connected neurohormone with digestive enzyme activity under the osmotic environment. Further research is needed to determine whether the increase in digestive enzyme activity is regulated by hormone regulation in different salinity environments.

Field investigation performed on indigenous and invasive E. sinensis showed that males descended to brackish waters first and the females followed within a month (Anger 1991, Du 2004). Elevated salinity will stimulate the locomotor activity of mature $E$. sinensis, especially in males (Normant et al. 2012); males showed reproductive behaviour first. In the present study, all digestive enzyme activities except that of lipase in males increased significantly when salinity was increased to $14 \mathrm{ppt}$. This digestive adjustment at biochemical level could be correlated with the elevated energy requirements for their reproductive behaviour and gametogenesis due to the salinity stimulation. Increased energy requirements will accelerate the attempt of crabs to derive more nutrients from a certain amount of food. After mating, females move into the more saline parts of the estuary and release their larvae in early spring (Herborg et al. 2006), while males seem not to need to undergo relatively high salinity. Different missions of females and males might suggest that females need a greater adaptability to high salinity than males at the biochemical and physiological levels. We detected that the initial salinity that induced the decrease in digestive enzyme activity in males (21 ppt) was lower than that in females (28 ppt), indicating that the digestive ability of females was more tolerant to higher salinity than that of males. Such an obvious discrepancy between sexes could be associated with the salinity that they experience during reproductive migration.

The results of the present study showed that digestive enzyme activities in hepatopancreas were approximately two or three times higher in males than in females at some salinity. This finding is consistent with previous research on sexual difference of adult $E$. sinensis dealing with digestive, ecological and physical aspects (Ye et al. 2000). Powerful chelae and pereiopods make males stronger for feeding, predating and creeping than females. These abilities might be responsible for their higher digestive enzyme activities. Based on findings by Ye et al. (2000) and results in the present study, it is tempting to speculate that sexual difference of digestive enzyme activity is related to locomotor activity and feeding ability.

This study has demonstrated that five digestive enzymes participated in the digestive adjustment of mature $E$. sinensis after acclimatation to elevated salinity. Higher amylase and cellulose activity in hepatopancreas suggests the great ability to digest carbohydrate. The fact that the decrease in digestive enzyme activities occurred earlier in males than in females after increasing salinity might indicate that females were more tolerant to high salinity than males from the viewpoint of digestive biochemistry. Elevated digestive enzyme activities of males at $14 \mathrm{ppt}$ were correlated with the increased energy requirements for their reproductive behaviour and gametogenesis due to the salinity stimulation. Re- 
duction in digestive enzyme activity at near to an isoosmotic environment could be an adaptive adjustment to a low-energy requirement. This study contributes to a better understanding of the complexity of biochemical adaptation to salinity increase in hyper-regulating crustaceans.

\section{ACKNOWLEDGEMENTS}

This research was supported by the Special Fund for Agro-Scientific Research in the Public Interest (No.200903048-07 and No.201203065), the National Basic Research Programme of China (973 Programme) (2010CB429005) and the Special Research Fund for the National Non-Profit Institutes of China (East China Sea Fisheries Research Institute, 2011M08).

\section{REFERENCES}

Anger K. 1991. Effects of temperature and salinity on the larval development of the Chinese mitten crab Eriocheir sinensis (Decapoda: Grapsidae). Mar. Ecol. Prog. Ser. 72: 103-110.

Anger K. 2001. The biology of decapod crustacean larvae. Crustacean Issues 14: 1-420.

Asaro A., Valle J.C.D., Mañanes A.A.L. 2011. Amylase, maltase and sucrase activities in hepatopancreas of the euryhaline crab Neohelice granulata (Decapoda: Brachyura: Varunidae): partial characterization and response to low environmental salinity. Sci. Mar. 75: 517-524.

Chen B.L., Du N.S., Ye H.F. 1989. Diet analysis of Chinese mitten crab, Eriocheir sinensis. Fish. Sci. Technol. Inform. 16: 2-5 (in Chinese, with English abstract).

Coccia E., Varricchio E., Paolucci M. 2011. Digestive enzymes in the crayfish Cherax albidus: polymorphism and partial characterization. Inter. J. Zool. 2011: 1-9.

Crawford A.C., Kricker J.A., Anderson A.J., Richardson N.R., Mather P.B. 2004. Structure and function of a cellulase gene in redclaw crayfish, Cherax quadricarinatus. Gene 340: 267-274.

Curtis D.L., McGaw I.J. 2010. Respiratory and digestive responses of postprandial Dungeness crabs, Cancer magister, and blue crabs, Callinectes sapidus, during hyposaline exposure. J. Comp. Physiol. B 180: 189-198.

Du N.S. 2004. Migration of Chinese mitten crab Eriocheir sinensis. Fish. Sci. Technol. Inform. 31: 56-57 (in Chinese, with English abstract).

Elyakova L.A., Shevchenko N.M., Avaeva S.M. 1981. A comparative study of carbohydrase activities in marine invertebrates. Comp. Biochem. Physiol. B 69: 905-908.

Fanjul-Moles M.L. 2006. Biochemical and functional aspects of crustacean hyperglycemic hormone in decapod crustaceans: Review and update. Comp. Biochem. Physiol. C 142: 390-400.

Freire C.A., Onken H., McNamara J.C. 2008. A structure function analysis of ion transport in crustacean gills and excretory organs. Comp. Biochem. Physiol. A 151: 272-304.

Gargouri Y., Julien R., Sugihara A., Sarda L., Verger R. 1984. Inhibition of pancreatic and microbial lipases by proteins. Biochim. Biophys. Acta 795: 326-331.

Gjellesvik D.R., Lorens J.B., Male R. 1992. Pancreatic carboxylester lipase from Atlantic salmon (Salmo salar): cDNA sequence and computer-assisted modeling of tertiary structure. Eur. J. Biochem. 226: 603-612.

Herborg L.M., Bentley M.G., Clare A.S., Last K.S. 2006. Mating behaviour and chemical communication in the invasive Chinese mitten crab Eriocheir sinensis. J. Exp. Mar. Biol. Ecol. 329: $1-10$

Herborg L.M., Rushton S.P., Clare A.S., Bentley M.G. 2003. Spread of the Chinese mitten crab (Eriocheir sinensis H. Milne Edwards) in Continental Europe: analysis of a historical data set. Hydrobiologia 503: 21-28.

Hochachka P.W., Somero G.N. 1984. Biochemical adaptation. Princeton University Press, Princeton.
Hymanson Z., Wang J., Sasaki T. 1999. Lessons from the home of the Chinese mitten crab. Interagency Ecol. Progr. News. Let. 12: 25-32.

Jiang H.B., Chen L.Q., Wang Q., Zhao X.Q., Yu N., Ni J. 2005. Effects of dietary protein on activities of digestive enzyme and trypsin mRNA abundance in Eriocheir sinensis juvenile. $J$. Fish. China 29: 216-221 (in Chinese, with English abstract).

Johnston D.J. 2003. Ontogenetic changes in digestive enzyme activity of the spiny lobster, Jasus edwardsii (Decapoda; Palinuridae). Mar. Biol. 143: 1071-1082.

Johnston D., Freeman J. 2005. Dietary preference and digestive enzyme activities as indicators of trophic resource utilization by six species of crab. Biol. Bull. 208: 36-46.

Kamemoto F.I. 1991. Neuroendocrinology of osmoregulation in crabs. Zool. Sci. 8: 827-833.

Kinne O. 1966. Physiological aspects of animal life in estuaries with special reference to salinity. Neth. J. Sea. Res. 3: 222-244.

Li E., Chen L., Zeng C., Yu N., Xiong Z., Chen X., Qin J.G. 2008. Comparison of digestive and antioxidant enzymes activities, haemolymph oxyhemocyanin contents and hepatopancreas histology of white shrimp, Litopenaeus vannamei, at various salinities. Aquaculture 274: 80-86.

Li G.L., Li S.F. 1996. Preliminary study on digestive enzymes of mitten crab, Eriocheir sinensis in changjiang, oujiang and liaohe rivers. J. Shanghai Fish. Univ. 5: 134-137 (in Chinese, with English abstract).

Liu Y.M., Zhu J.Z., Wu H.Y., Shi D.Z. 1991. Studies on digestive enzymes and amino acids of larval and post larval stages of prawn Penaeus chinensis (O'Sbeck 1965). Oceanol. Limnol. Sinica 22: 571-574 (in Chinese, with English abstract).

López-López S., Nolasco H., Vega-Villasante F. 2003. Characterization of digestive gland esterase-lipase activity of juvenile redclaw crayfish Cherax quadricarinatus. Comp. Biochem. Physiol. B 135: 337-347.

Mantel L.H. 1985. Neurohormonal integration of osmotic and ionic regulation. Am. Zool. 25: 253-263.

Morris S. 2001. Neuroendocrine regulation of osmoregulation and the evolution of air-breathing in decapod crustaceans. J. Exp. Biol. 204: 979-989.

Normant M., Król M., Jakubowska M. 2012. Effect of salinity on the physiology and bioenergetics of adult Chinese mitten crabs Eriocheir sinensis. J. Exp. Mar. Biol. Ecol. 416-417: 215-220.

Pan L.Q., Wang K.Q. 1997a. Studies on digestive enzyme activities and amino acid in the larvae of Portunus trituberculatus. J. Fish. China 21: 246-251 (in Chinese, with English abstract).

Pan L.Q., Wang K.Q. 1997b. Studies on digestive enzymes activities and amino acid in the larvae of Eriocheir sinensis. J. Fish. Sci. China 4: 13-20 (in Chinese, with English abstract).

Panning A. 1938. The Chinese mitten crab. Annu. Rep. Smithson. Inst 361-375.

Pavasovic M., Richardson N.A., Anderson A.J., Mann D., Mather P.B. 2004. Effect of $\mathrm{pH}$, temperature and diets on digestive enzyme profiles in the mud crab, Scylla serrata. Aquaculture 242: 641-654.

Péqueux A., Gilles R. 1981. $\mathrm{Na}^{+}$fluxes across isolated perfused gills of the Chinese crab Eriocheir sinensis. J. Exp. Biol. 92: 173-186.

Rathelot J., Julien R., Canioni P., Coeroli C., Sarda L. 1975. Studies on the effect of bile salt and colipase on enzymatic lipolysis, improved method for the determination of pancreatic lipase and colipase. Biochimie 57: 1117-1122.

Rathmayer M., Siebers D. 2001. Ionic balance in the freshwateradapted Chinese crab, Eriocheir sinensis. J. Comp. Physiol. B 171: 271-281.

Rick W., Stegbauer H.P. 1984. Alfa-amylase. In: Bergmeyer H.U., Grab, M. (eds), Methods of Enzymatic Analysis. Enzymes, vol. 5. Academic Press, New York, pp. 885-889.

Roast S.D., Rainbow P.S., Smith B.D., Nimmo M., Jones M.B. 2002. Trace metal uptake by the Chinese mitten crab Eriocheir sinensis: the role of osmoregulation. Mar. Environ. Res. 53: 453-464.

Rudnick D., Halat K., Resh V. 2000. Distribution, ecology and potential impacts of the Chinese mitten crab (Eriocheir sinensis) in San Francisco Bay. University of California Water Resources Center, \#206, 74 pp.

Rudnick D., Veldhuizen T., Tullis R., Culver C., Hieb K., Tsukimura B. 2005. A life history model for the San Francisco Estuary 
population of the Chinese mitten crab, Eriocheir sinensis (Decapoda: Grapsoidea). Biol. Invasions 7: 333-350.

Shi W.G., Xie J., Zhou E.H. 2000. Ontogenetic changes in digestive enzyme activity of the Chinese mitten crab E. sinensis. J. Zhan Jiang Ocean Univ. 20: 67-70. (in Chinese, with English abstract)

Velurtas S.M., Díaz A.C., Fernández-Gimenez A.V., Fenucci J.L. 2011. Influence of dietary starch and cellulose levels on the metabolic profile and apparent digestibility in penaeoid shrimp. Lat. Am. J. Aquat. Res. 39: 214-224.

Wang R.F., Zhuang P., Feng G.P., Zhang L.Z., Huang X.R., Jia X.Y. 2012. Osmoic and ionic regulation and $\mathrm{Na}^{+} / \mathrm{K}^{+}$-ATPase, carbonic anhydrase activities in mature Chinese mitten crab Eriocheir sinensis exposed to different salinities. Crustaceans 85: 1431-1447.

Wormhoudt Van A. 1974. Variations of the level of the digestive enzymes during the intermolt cycle of Palaemon serratus: influence of the season and effect of the eyestalk ablation. Comp. Biochem. Physiol. 49: 707-715.

Yang Z.B., Zhao Y.L., Zhou Z.L., Zhou X., Yang J. 2005. Effects of copper in water on distribution of copper and digestive enzyme activities in Eriocheir sinensis. J. Fish. China 29: 496-501 (in Chinese, with English abstract).

Ye Y.T., Lin S.M., Luo L., Zeng D., Zhou J.S. 2000. Comparative study of partial character of pond-reared females and males Chinese mitten crab, Eriocheir sinensis. Inland Fish. 4: 7-8 (in Chinese, with English abstract).

Yokoe Y., Yasumasu I. 1964. Distribution of cellulose in invertebrates. Comp. Biochem. Physiol. 13: 323-338.

Zhao Y.M., Wang X.H., Qin Y.W., Zheng B.H. 2010. Mercury $\left(\mathrm{Hg}^{2+}\right)$ effect on enzyme activities and hepatopancreas histostructures of juvenile Chinese mitten crab Eriocheir sinensis. Chinese J. Oceanol. Limnol. 28: 427-434 (in Chinese, with English abstract).

Zhou Y.K., Liu L.H., Chen L.Q., Yu F.J., Li E.C. 2005. Changes in digestive enzymes activity of ovarian development. Reservoir Fish. 25: 19-21 (in Chinese, with English abstract).

Scient. ed.: E. Macpherson.

Received September 12, 2012. Accepted March 7, 2013.

Published onllne April 15, 2013. 